\title{
POSTOPERATIVE NAUSEA AND VOMITING: THE RESPONSE TO ANTI-EMETIC DRUGS WITH SPECIAL REFERENCE TO CYCLIZINE AND PERPHENAZINE
}

\author{
HLLDA RoberTs, F.F.A.R.C.S. ${ }^{1}$
}

OVER THE PAST Two to three decades, advances in surgery have stimulated parallel advances in anaesthesia. In fact, it can be said that so many of the intricate surgical procedures would be impossible without the support of skilled anaesthetic techniques. An indication of the satisfactory progress of anaesthesia is the patient's expectation of a pleasant smooth induction and an uneventful recovery. There is no doubt that anaesthesia has attained its high standard by reason of scientific and clinical research carried out by anaesthetists and pharmacologists. However, in spite of refinements of preoperative sedation, anaesthetic technique, and careful supervision in the immediate postoperative period, the incidence of nausea and vomiting is still too high. As observed by Marcus and Sheehan (1), such complications only become highlighted when a recovery room is maintained and patients are seen together in the early postoperative period. Consequently the search for the satisfactory anti-emetic continues, and those which have been used with considerable success for travel sickness have been employed to reduce the occurrence of vomiting after operation. The anti-emetics in general use today tend to fall into two categories: (i) antihistamine compounds, for example, dimenhydrinate, cyclizine; (ii) tranquillizers, for example, chlorpromazine, promethazine, perphenazine, promazine.

It is of paramount importance that the many factors contributing towards postoperative vomiting should be appreciated, and attempts made to correct them before mere blind administration of palliative drugs is undertaken. Best and Taylor (2) maintain that the induction of vomiting can be due to such factors as:

(a) A reflex action arising from impulses from the stomach or other parts of the alimentary tract, extending from the pharynx downwards (irritation from blood, mucus, and irritant anaesthetic drugs entering the stomach itself will provide the necessary stimulus for vomiting)

(b) Central stimulation due to drugs which raise the excitability of the vomiting centre itself, for example, morphine and meperidine

Other causes of vomiting are discussed by Dent et al. (3). Impulses received from the cerebral centres in response to various stimuli, for example, rough handling of the patient during transfer from operating table to trolley and frequent changing of position during the early postoperative period, can be a factor in vomiting. Vestibular stimulation by morphine or anaesthetic drugs can increase the liability to vomiting. Best and Taylor consider that any interference with the blood supply to the vomiting centre either by haemorrhage or by tumour will

1 A ssoniate Chief of Anaesthesia, Women's Collegk Hospital, Toronto. 
stimulate vomiting. Anoxia is thought to be a very important source of stimulation, and any severe degree of anoxia has the same effect as impairment of blood supply. General disorders such as mental stress, hysteria or even fatigue can be the cause of postoperative vomiting, and it is conceded that the nervous, anxious patient is more likely to experience an unhappy recovery than the placid patient.

In an attempt to evaluate some of the inti-emetic drugs in postoperative vomiting a survey was undertaken. The modus operandi was as follow's:

Two general surgeons and two gynaecologists gave permission for their patients to receive the anti-emetic drugs under consideration, and the remainder of the surgical cases were observed as controls. The patients constituting the control group did not receive any of the anti-emetic drugs during the whole operative period including preoperative and immediate postoperative periods. Each group contained a similar cross-section of types of operations, and a similarity in anaesthetic techniques was maintained since all anaesthetists worked in each group. In all, 1,403 patients ( 1,389 females, 14 males) were observed in the recovery room and in the ward on subsequent days up to the fifth day. The ages of the patients observed ranged from 5 years to 85 years, with the majority in the middle range. Detailed records were kept on each patient. The main scrutiny concerning nausea and vomiting was made over the first 36 hours after operation since it was felt that many other extraneous factors cause or accentuate the gastric disturbance after that time. Some observers in this feld confine themselves to the first 12 hours at most, as they think that with modern anaesthesia the effects of the drugs should be eliminated by that time.

Only a brief résumé of the drugs used in this survey is presented since all of them have been well described in the literature.

1. Chlorpromazine is a derivative of phenothiazine and by reason of its neuroplegic action on the peripheral and central autonomic nervous system, it exhibits sedative and anti-emetic qualities, and also has the power to potentiate the activity of anaesthetic, analgesic and hypnotic drugs.

2. Promethazine, also a derivative of phenothiazine, has been shown to have antihistamine properties. It is also an anti-emetic and like chlorpromazirie possesses potentiating properties.

3. Perphenazine has similar qualities and is an amino derivative of chlorphenothiazine. Animal studies indicate that perphenazine is five to ten times as potent as chlorpromazine but only half as toxic.

4. Cyclizine hydrochloride is an antihistarnine and anticholinergic, and investigations indicate that it has a specific action on the parasympathetic ganglia.

\section{Mode of Admintstration of Drugs}

Cyclizine hydrochloride was administered in three ways:

(a) In the recovery room-by suppositorie; $100 \mathrm{mg}$. or $50 \mathrm{mg}$. intramuscularly if the operation involved the rectum or anus.

(b) Preoperatively with atropine and meperidine or pantopon. Because of the potentiating action of the cyclizine, it was found necessary to halve the amount of narcotic given. Therefore, the preoperative sedation was meperidine $50.0 \mathrm{mg}$., atropine $0.6 \mathrm{mg}$., cyclizịne $50.0 \mathrm{mg}$. intramuscularly. 
(c) Preoperative sedation as in (b) and supported by the administration of meperidine-promethazine-chlorpromazine or by meperidine-perphenazine during anaesthesia.

Meperidine-promethazine-chlorpromazine sequence was used in association with anaesthesia. The formula contained: meperidine $100 \mathrm{mg}$., promethazine $50 \mathrm{mg}$., chlorpromazine $50 \mathrm{mg}$., in $20 \mathrm{ml}$. of normal saline. The amount used during anaesthetic varied from 4 to $10 \mathrm{ml}$., depending on the length and type of operation.

Meperidine-p̀erphenazine was administered in the same way as the meperidinepromethazine-chlorpromazine combination. The amounts contained in the solution: meperidine $100 \mathrm{mg}$., perphenazine $50 \mathrm{mg}$., in $20 \mathrm{ml}$. of normal saline.

\section{Results}

The material in the survey presents a variety of surgical procedures, and since the observations of some workers indicate that the site of operation has an influence on the incidence of postoperative vomiting, it was deemed necessary to compare the distribution of operations in the control group and in the treated patients. Table I presents the variety of major operations in each group. There is some degree of imbalance in the distribution between the two groups, but it is felt that it is due, mainly, to the small number of major orthopaedic operations, and consequently the groups are considered comparable.

TABLE I

The Distribetion of the Types of Major Operations in the Control and Treated Groups

\begin{tabular}{|c|c|c|c|c|c|c|c|c|c|}
\hline & \multicolumn{8}{|c|}{ Operations } & \multirow[b]{2}{*}{ Total } \\
\hline & Breast & $\begin{array}{l}\text { Head } \\
\text { and } \\
\text { neck }\end{array}$ & $\begin{array}{c}\text { Gastro- } \\
\text { intes- } \\
\text { tinal }\end{array}$ & $\begin{array}{c}\text { Cholecy'st- } \\
\text { ectomie:s }\end{array}$ & $\begin{array}{c}\text { Pelvic } \\
\text { and other } \\
\text { abdomí- } \\
\text { nal }\end{array}$ & $\begin{array}{l}\text { Fothergill } \\
\text { repairs } \\
\text { vaginal } \\
\text { hysterec- } \\
\text { tomies }\end{array}$ & $\begin{array}{l}\text { Hernia } \\
\text { repairs }\end{array}$ & $\begin{array}{l}\text { Major } \\
\text { ortho- } \\
\text { paedic }\end{array}$ & \\
\hline \multicolumn{10}{|l|}{ Control group } \\
\hline $\begin{array}{l}\text { Observed } \\
\text { values } \\
\text { Expected }\end{array}$ & 16.00 & 15.00 & 37.00 & 28.00 & 126.00 & 26.00 & 11.00 & 7.00 & 266.00 \\
\hline $\begin{array}{c}\text { values } \\
\chi^{2}\end{array}$ & $\begin{array}{r}21.26 \\
1.30\end{array}$ & $\begin{array}{r}10.33 \\
2.11\end{array}$ & $\begin{array}{r}28.64 \\
2.44\end{array}$ & $\begin{array}{r}35.43 \\
1.56\end{array}$ & $\begin{array}{r}125.77 \\
.00\end{array}$ & $\begin{array}{r}27.75 \\
.11\end{array}$ & $\begin{array}{r}13.28 \\
.39\end{array}$ & $\begin{array}{l}3.54 \\
3.38\end{array}$ & $\begin{array}{r}266.00 \\
11.29\end{array}$ \\
\hline $\begin{array}{l}\text { Treated group } \\
\text { Observed } \\
\text { values } \\
\text { 'Expected }\end{array}$ & 56.00 & 20.00 & 60.00 & 92.00 & 300.00 & 68.00 & 34.00 & 5.00 & 635.00 \\
\hline $\begin{array}{c}\text { values } \\
x^{2}\end{array}$ & $\begin{array}{r}50.74 \\
.55\end{array}$ & $\begin{array}{r}24.67 \\
.88\end{array}$ & $\begin{array}{r}68.36 \\
1.02\end{array}$ & $\begin{array}{r}84.57 \\
.65\end{array}$ & $\begin{array}{r}300.23 \\
.00\end{array}$ & $\begin{array}{r}66.25 \\
.05\end{array}$ & $\begin{array}{r}31.72 \\
.52\end{array}$ & $\begin{array}{l}8.46 \\
1.42\end{array}$ & $\begin{array}{r}635.00 \\
5.09\end{array}$ \\
\hline TOTAL & .72 .00 & 35.00 & 97.00 & 120.00 & 426.00 & 94.00 & 45.00 & 12.00 & $\begin{array}{r}901.00 \\
16.38\end{array}$ \\
\hline
\end{tabular}

$\chi^{2}=16.38 . \quad 7 \mathrm{df} . \quad P<0.05$.

During the course of the observations a variety of anaesthetic techniques was employed, and to estimate the effect, if any, of the main types of anaesthesia on the incidence of postoperative vomiting, Table II was constructed. The three anaesthetics presented were given in conjunction with thiopentone, and where 
TABBLE II

The Effect of Different Anaesthetics on the Postoperative Vomiting: MAJOR, OPERATIONS

\begin{tabular}{|c|c|c|c|c|}
\hline & Nitrous oxide & Iolatile anaesthetic & Cyclopropane & Total \\
\hline \multicolumn{5}{|l|}{ Absence of romiting } \\
\hline Observed values & 266.00 & 195.00 & 65.00 & 526.00 \\
\hline Expected values & 238.19 & 209.00 & 78.81 & 526.00 \\
\hline$x^{2}$ & 3.25 & .94 & 2.42 & 6.61 \\
\hline \multicolumn{5}{|c|}{ One episode of voniting } \\
\hline Observed values & 75.00 & 91.00 & 43.00 & 211.00 \\
\hline Expected values & 95.55 & 83.84 & 31.61 & 211.00 \\
\hline$x^{2}$ & 3.60 & .61 & 4.10 & 8.31 \\
\hline \multicolumn{5}{|l|}{$\begin{array}{l}\text { More than one episode } \\
\text { of romiting }\end{array}$} \\
\hline Observed values & 65.00 & 7.2 .00 & 27.00 & 164.00 \\
\hline Expected values & 74.26 & 65.16 & 24.58 & 164.00 \\
\hline$x^{2}$ & 1.15 & .72 & .24 & 2.11 \\
\hline Total & 408.00 & 3.58 .00 & 135.00 & 901.00 \\
\hline
\end{tabular}

necessary, relaxant drugs were used. 'There is a significant increase in the amount of postoperative vomiting in the patients receiving a volatile anaesthetic, and also in the cyclopropane group. In the latter patients the increase appears to be more confined to one episode of vomiting. Since it is felt that the type of anaesthetic does influence the results in this series, a study of the distribution of the types of anaesthetics used in each group of anti-emetic treatment is presented. Table III shows this distribution, and it is seen that the patients in the control group received more volatile anaesthetics and cyclopropane than those given anti-emetics. A further analysis was made of each anti-emetic group and also of the controls. In every such group the incidence of vomiting was studied in relation to the type of anaesthetic used; but it was found that none of the tables produced significant

TABLE III

Thf. Distribution of Types of General Anaesthesia in Relation to Anti-emetic Drugs: Major Operations

\begin{tabular}{|c|c|c|c|c|}
\hline & Nitrous oxide & Volatile anaesthetic & Cyclopropane & Total \\
\hline \multicolumn{5}{|l|}{ Controls } \\
\hline Observed values & 82.00 & 132.00 & 52.00 & 266.00 \\
\hline Expected values & 120.45 & 105.69 & 29.86 & 266.00 \\
\hline$x^{2}$ & 12.27 & 6.55 & 3.70 & 22.52 \\
\hline \multicolumn{5}{|l|}{ Meperidine and } \\
\hline $\begin{array}{l}\text { tranquillizer } \\
\text { Observed values }\end{array}$ & 140.00 & 100.00 & 27.00 & 267.00 \\
\hline Expected values & 120.91 & 106.09 & 40.00 & 267.00 \\
\hline$x^{2}$ & 3.01 & .35 & 4.23 & 7.59 \\
\hline \multicolumn{5}{|l|}{ Combined cyclizine } \\
\hline $\begin{array}{l}\text { groups } \\
\text { Observed values }\end{array}$ & 186.00 & 126.00 & 56.00 & 368.00 \\
\hline Expected values & 166.64 & 146.22 & 55.14 & 368.00 \\
\hline$x^{2}$ & 2.25 & 2.80 & .01 & 5.06 \\
\hline TOTAL & 408.00 & 358.00 & 135.00 & $\begin{array}{r}901.00 \\
35.17\end{array}$ \\
\hline
\end{tabular}


TABLE: IV

An Analysis of Patients Receiving Nitrous Oxide Supported by Thiopentone, With or without Relayant Druc: Major Operations

\begin{tabular}{|c|c|c|c|c|}
\hline & $\begin{array}{l}\text { Absence of } \\
\text { vomiting }\end{array}$ & $\begin{array}{l}\text { One episode of } \\
\text { vomiting }\end{array}$ & $\begin{array}{l}\text { More than one } \\
\text { episode }\end{array}$ & Total \\
\hline \multicolumn{5}{|l|}{ Controls } \\
\hline Observed values & 36.00 & 23.00 & 23.00 & 82.00 \\
\hline Expected values & 53.26 & 15.68 & 13.06 & 82.00 \\
\hline$\chi^{2}$ & 5.59 & 3.42 & 7.56 & 16.57 \\
\hline \multicolumn{5}{|c|}{$\begin{array}{l}\text { Meperidine-tranquillizer } \\
\text { seouences }\end{array}$} \\
\hline Observed values & 99.00 & 30.00 & 11.00 & 140.00 \\
\hline Expected values & 90.94 & 26.76 & 22.30 & 140.00 \\
\hline$\chi^{2}$ & .71 & .39 & 5.73 & $618: 3$ \\
\hline \multicolumn{5}{|l|}{ Cyclizine } \\
\hline Observed values & 130.00 & 25.00 & 31.00 & 186.00 \\
\hline Expected values & 120.81 & 35.56 & 29.63 & 186.00 \\
\hline$x^{2}$ & .70 & 3.14 & .06 & 3.90 \\
\hline TOTAL & 265.00 & 78.00 & 65.00 & $\begin{array}{r}408.00 \\
27.30\end{array}$ \\
\hline
\end{tabular}

$\chi^{2}=27.30 . \quad 4 \mathrm{df} . \quad P<0.01$.

results. This appeared to indicate a fairly steady action on the part of the individual anti-emetics whatever anaesthetic was employed. However, an analysis of the individual anaesthetic groups (Tables IV and V) points to the significant effect of meperidine-tranquillizer administrations. The numbers in Table VI are rather too small to be effective.

Table VII analyses the postoperative yomiting after major operations in the control group and the meperidine-tranquillizer series. The effect of the latter is significant. Patients receiving cyclizine are presented in three groups in Table VIII which shows the most satisfactory results are obtained when the cyclizine is supported by meperidine and tranquillizer. Comparisons of the main groups

TABLE $I^{\prime}$

The Incidence of Postoperative lomiting after the lise of Volatile: Anaesthetics: MAJOR OPERATIONS

\begin{tabular}{|c|c|c|c|c|}
\hline & $\begin{array}{l}\text { Absence of } \\
\text { vomiting }\end{array}$ & $\begin{array}{l}\text { One episode of } \\
\text { romiting }\end{array}$ & $\begin{array}{l}\text { More than one } \\
\text { episode }\end{array}$ & Total \\
\hline \multicolumn{5}{|l|}{ Controls } \\
\hline Observed values & 57.00 & 20.00 & 46.00 & 132.00 \\
\hline Expected values & 71.90 & 33.55 & 26.55 & 132.00 \\
\hline$x^{2}$ & 3.09 & .62 & 14.25 & 17.90 \\
\hline \multicolumn{5}{|c|}{$\begin{array}{l}\text { Meperidine-tranquillizer } \\
\text { sequences }\end{array}$} \\
\hline Observed values & 69.00 & 29.00 & 2,00 & 100.00 \\
\hline Expected values & $5+.47$ & 2542 & 20.11 & 100.00 \\
\hline$x^{2}$ & 388 & .50 & 16.31 & 20.69 \\
\hline Cyclizine & & & & : \\
\hline Observed values & 6iी.00 & 33.00 & 24.00 & 126.00 \\
\hline Expected values & 68.63 & $3: 03$ & 25.34 & 126.00 \\
\hline$x^{2}$ & .00 & .03 & .07 & .10 \\
\hline TOTAL & 195.00 & $9 ! .00$ & 72.00 & $\begin{array}{r}358.00 \\
38.75\end{array}$ \\
\hline
\end{tabular}


HILDA ROBERTS: POSTOPERATIVE NAUSFA AND VOMTTING

TABLE VI

An Analysis of the Effect of Cyclopropane Anaesthesia: MAJOR OpERATIONS

\begin{tabular}{|c|c|c|c|c|}
\hline & $\begin{array}{l}\text { Absence of } \\
\text { vomiting }\end{array}$ & $\begin{array}{c}\text { One episode of } \\
\text { romiting }\end{array}$ & $\begin{array}{l}\text { More than one } \\
\text { episode }\end{array}$ & Total \\
\hline \multicolumn{5}{|l|}{ Controls } \\
\hline Observed values & 22.00 & 18.00 & 12.00 & 52.00 \\
\hline Expected values & 25.42 & 16.18 & 10.40 & 52.00 \\
\hline$\chi^{2}$ & .46 & .20 & .25 & .91 \\
\hline \multicolumn{5}{|c|}{$\begin{array}{l}\text { Meperidine-tranquillizer } \\
\text { sequences }\end{array}$} \\
\hline Observed values & 19.00 & 8.00 & .00 & 27.00 \\
\hline Expected values & 13.20 & 8.40 & 5.40 & 27.00 \\
\hline$x^{2}$ & 2.55 & $\begin{array}{r}0.40 \\
.02\end{array}$ & 5.40 & 7.97 \\
\hline \multicolumn{5}{|l|}{ Cyclizine } \\
\hline Observed values & 25.00 & 16.00 & 15.00 & 56.00 \\
\hline Expected values & 27.38 & 17.42 & 11.20 & 56.00 \\
\hline $\begin{array}{c}\chi^{-} \\
\text {Totar }\end{array}$ & 600 & 400 & 2700 & 13500 \\
\hline 1OTAL & 00.00 & +2.40 & & $\begin{array}{r}100.00 \\
10.50\end{array}$ \\
\hline
\end{tabular}

(Tables IX and X) show highly significant results in favour of the meperidinetranquillizer treatment. Similar analyses of the 760 minor operation cases did not give any significant results, and this may have been due to the fact that very few patients received the meperidine-tranquillizer treatment.

Observations were made on 401 patients who experienced postoperative vomiting. Type of operation, anaesthetic received, and any prophylactic treatment given preoperatively or during operation were not taken into consideration. The anti-emetic given for the treatment of the vomiting was left to the discretion of the surgeon concerned. The drugs used were cyclizine and dimenhydrinate and

TABLE VII

The Relation bétween Postoperative lomiting and the Type of Anti-emetic ADMINISTERED DURING ANAESTHESIA FOR MAJOR OPERATIONS

\begin{tabular}{|c|c|c|c|c|}
\hline & $\begin{array}{l}\text { Absence of } \\
\text { vomiting }\end{array}$ & $\begin{array}{l}\text { One episode of } \\
\text { vomiting }\end{array}$ & $\begin{array}{l}\text { More than one } \\
\text { episode }\end{array}$ & Total \\
\hline \multicolumn{5}{|l|}{ Control group } \\
\hline Observed values & 115.00 & 70.00 & 81.00 & 266.00 \\
\hline $\begin{array}{l}\text { Expected values } \\
\chi^{2}\end{array}$ & $\begin{array}{r}150.70 \\
8.46\end{array}$ & $\begin{array}{r}68.40 \\
.04\end{array}$ & $\begin{array}{l}46.90 \\
24.80\end{array}$ & $\begin{array}{r}266.00 \\
33.30\end{array}$ \\
\hline \multicolumn{5}{|c|}{$\begin{array}{l}\text { Meperidine-promethazine- } \\
\text { chlorpromazine during } \\
\text { anaesthesia }\end{array}$} \\
\hline Observed values & 103.00 & 45.00 & 7.00 & 155.00 \\
\hline Expected values & 87.80 & 39.80 & 27.40 & 155.00 \\
\hline$\chi^{2}$ & 2.63 & .68 & 15.09 & 18.40 \\
\hline \multicolumn{5}{|c|}{ Meperidine-perphenazine } \\
\hline Observed values & 84.00 & 22.00 & 6.00 & 112.00 \\
\hline Expected values & 63.50 & 28.80 & 19.70 & 112.00 \\
\hline$\chi^{2}$ & 6.69 & 1.61 & 9.62 & 17.92 \\
\hline TOTAL & 302.00 & 137.00 & 94.00 & $\begin{array}{r}533.00 \\
69.62\end{array}$ \\
\hline
\end{tabular}

$x^{2}=69.62 . \quad 4 \mathrm{df} . \quad P<0.001$. 
TABLE VIII

The Incidence of Postoperative Vomiting in the Cyclizine series: Major OPERATIONS

\begin{tabular}{|c|c|c|c|c|}
\hline & $\begin{array}{l}\text { Absence of } \\
\text { romiting }\end{array}$ & $\begin{array}{l}\text { One episode of } \\
\text { vomiting }\end{array}$ & $\begin{array}{l}\text { More than one } \\
\text { episode }\end{array}$ & Total \\
\hline \multicolumn{5}{|l|}{ Cyclizine given in } \\
\hline Observed values & 31.00 & 18.00 & 22.00 & 71.00 \\
\hline Expected values & +3.22 & $1 \neq .28$ & 13.50 & 71.00 \\
\hline$x^{2}$ & 3.46 & .97 & 5.35 & 9.78 \\
\hline \multicolumn{5}{|l|}{$\begin{array}{l}\text { Cyclizine given } \\
\text { preoperatively }\end{array}$} \\
\hline Observed values & 72.00 & $3 \approx 00$ & 37.00 & 146.00 \\
\hline Expected values & 88.87 & 29.36 & 27.77 & 166.00 \\
\hline$\chi^{2}$ & 3.20 & 1.99 & 3.07 & 8.26 \\
\hline \multicolumn{5}{|c|}{$\begin{array}{l}\text { Cyclizine given } \\
\text { preoperatively, } \\
\text { supported by } \\
\text { meperidine-tranquillizer } \\
\text { sequences }\end{array}$} \\
\hline Observed values & 121.00 & 19.00 & 11.00 & 151.00 \\
\hline Expected ralues & 91.91 & 30.26 & 28.73 & 151.00 \\
\hline$\chi^{2}$ & 921 & 4.25 & 10.94 & 24.40 \\
\hline TOTAL & 22400 & $7+4.00$ & 70.00 & $\begin{array}{r}368.00 \\
42.44\end{array}$ \\
\hline
\end{tabular}

observations were made after the administration of a maximum of two doses at 4-hour intervals within 36 hours after operation. A number of patients received no treatment for vomiting within the same period of time, and have been recorded as controls. Table XI compares the observations made on the three groups. Cyclizine presents the most satisfactory results and there is a significant reduction in vomiting following its administration. Dimenhydrinate produces little effect, if any at all, on the incidence of vomiting.

TABLE IX

Results of the Meperidine-Tranqulllier Sequences aNd Cúclizine AdMinistrations: Major Operations

\begin{tabular}{|c|c|c|c|c|}
\hline & $\begin{array}{l}\text { Absence of } \\
\text { vomiting }\end{array}$ & $\begin{array}{l}\text { One episode of } \\
\text { romiting }\end{array}$ & $\begin{array}{l}\text { More than one } \\
\text { episode }\end{array}$ & Tot.1] \\
\hline \multicolumn{5}{|l|}{ Controls } \\
\hline Observed values & 115.00 & 70.00 & 81.00 & 266.00 \\
\hline Expected values & 155.00 & 62.29 & 48.42 & 266.00 \\
\hline$\chi^{2}$ & 10.45 & .95 & 21.92 & 33.32 \\
\hline \multicolumn{5}{|c|}{ Crombined meperidine- } \\
\hline Observed values & 187.00 & 6.00 & 13.00 & 267.00 \\
\hline Expected values & 155.87 & 02.53 & 48.60 & 267.00 \\
\hline$x^{3}$ & 6.22 & .32 & 26.08 & 32.62 \\
\hline \multicolumn{5}{|l|}{$\begin{array}{l}\text { Combined cyclizine } \\
\text { administrations }\end{array}$} \\
\hline Observed values & $22+1.00$ & $7+00$ & 70.00 & 368.00 \\
\hline Expected values & 214.84 & 86.18 & 66.98 & 368.00 \\
\hline$x^{2}$ & .39 & 1.72 & .14 & 2.25 \\
\hline TOTAL & 526.010 & 211.00 & 164.00 & $\begin{array}{r}901.00 \\
68.19\end{array}$ \\
\hline
\end{tabular}


TABLE $X$

Results with Patients Receiving Both Cyclizine and the Meperidine-Tranquillizer Sequence Eliminated from the Cyclizine Group: Major Operations

\begin{tabular}{|c|c|c|c|c|}
\hline & $\begin{array}{l}\text { Absence of } \\
\text { vomiting }\end{array}$ & $\begin{array}{l}\text { One episode of } \\
\text { vomiting }\end{array}$ & $\begin{array}{l}\text { More than one } \\
\text { episode }\end{array}$ & Total \\
\hline \multicolumn{5}{|l|}{ Controls } \\
\hline Observed values & 115.00 & 70.00 & 81.00 & 266.00 \\
\hline Expected values & 143.64 & 68.10 & 54.26 & 266.00 \\
\hline$x^{2}$ & 5.71 & .05 & 13.18 & 18.94 \\
\hline \multicolumn{5}{|c|}{$\begin{array}{l}\text { Combined meperidine- } \\
\text { tranquillizer sequences }\end{array}$} \\
\hline Observed values & 187.00 & 67.00 & 13.00 & $26 \pi .00$ \\
\hline Expected values & 144.18 & 68.35 & 54.47 & 267.00 \\
\hline$\chi^{2}$ & 12.72 & .03 & 31.57 & 44.32 \\
\hline \multicolumn{5}{|c|}{$\begin{array}{l}\text { Cyclizine } \\
\text { (a) preoperatively; } \\
\text { (b) in the recovery room }\end{array}$} \\
\hline Observed values & 103.00 & 55.00 & 59.00 & 217.00 \\
\hline $\begin{array}{l}\text { Expected values } \\
\chi^{2}\end{array}$ & $\begin{array}{r}117.18 \\
1.72\end{array}$ & $\begin{array}{r}.55 .55 \\
.00\end{array}$ & $\begin{array}{r}+4.27 \\
4.90\end{array}$ & $\begin{array}{r}217.00 \\
6.62\end{array}$ \\
\hline Total & 405.00 & 192.00 & 153.00 & $\begin{array}{r}750.00 \\
69.88\end{array}$ \\
\hline
\end{tabular}

\section{Discussion}

The structural formulae of the phenothiazine derivatives show a close relationship, but this likeness is not always borne out in their pharmacological actions. They do possess, however, certain common properties, and the anti-emetic action is common to most of them. The two sequences employed in this investigation, that is, meperidine-promethazine-chlorpromazine and meperidine-perphenazine, do present a very definite improvement in the incidence of postoperative vomiting. The improvement may be due to two things: $(a)$ the central action of the tranquillizers preventing vomiting; $(b)$ the potentiation of anaesthetic agents, thus reducing the amount of potential nauseants used, as shown in Table III.

TABLE XI

Response to Three Methods of Approach to Postoperative Vomiting

\begin{tabular}{|c|c|c|c|}
\hline & $\begin{array}{l}\text { Cessation of } \\
\text { vomiting }\end{array}$ & $\begin{array}{l}\text { Contiaued } \\
\text { romiting }\end{array}$ & Total \\
\hline \multicolumn{4}{|c|}{ Cyclizine postôperatively } \\
\hline Observed values & 137.00 & 62.00 & 199.00 \\
\hline Expected values & 120.59 & 78.41 & 199.00 \\
\hline$\chi^{2}$ & 2.23 & 3.43 & 5.66 \\
\hline \multicolumn{4}{|l|}{ Dimenhydrinate } \\
\hline Observed values & 46.00 & +2.00 & 88.00 \\
\hline Expected values & 53.33 & 34.67 & 88.00 \\
\hline$\chi^{2}$ & 1.01 & 1.55 & 2.56 \\
\hline \multicolumn{4}{|l|}{ No treatment given } \\
\hline Observed values & 60.00 & 54.00 & 114.00 \\
\hline Expected values & $\begin{array}{r}69.08 \\
1.19\end{array}$ & $\begin{array}{r}+1.92 \\
1.84\end{array}$ & $\begin{array}{r}11+.00 \\
3.03\end{array}$ \\
\hline Total & 243.00 & 158.00 & 401.00 \\
\hline
\end{tabular}


The meperidine-perphenazine combination superseded the meperidine-promethazine-chlorpromazine sequence in this survey since it was found that the former provided a very smooth recovery period, and that its administration during anaesthesia did not produce the hypotension created by meperidine-promethazinechlorpromazine. So far, perphenazine has not been found guilty of causing liver damage or agranulocytosis, but reported Parkinson-like reactions to oral perphenazine have indicated its ability to cause extra-pyramidal dysfunction. Robbie (4) describes two patients exhibiting such dysfunction after multiple doses of intramuscular injections of perphenazine. The tranquillizers present a fascinating and complex study to anaesthetists, and in using them for a specific purpose one must be fully aware of their other properties. According to Hiebel et al. (5) both chlorpromazine and promethazine have the unique property of depressing the arousal mechanism of the reticular activating system without affecting the cortical regions, and since areas in the reticular system are responsible for the control of muscle tone, vasomotor tone (Back (6)), respiratory activity, and the act of vomiting (Borison et al. (7)), the results of such depression need careful consideration.

The preoperative cyclizine administrations do not present any significant relief in the incidence of postoperative vomiting. As far as this survey is concerned, it is thought that in some of the cases receiving cyclizine preoperatively, a delay in starting the operation and a prolonged operating time could have impaired the action of the anti-emetic drug in the recovery period. Under such circumstances a second intramuscular injection of cyclizine at the termination of the operation, or in the recovery room, might have prolonged its effectiveness. Observations by Chinn et al. (8) on certain antihistamine drugs lead them to think that prophylaxis does not depend on the antihistamine action of these drugs, but on the cholinergic effect. This would explain the effectiveness of drugs with a central atropine-like action, for example, scopolamine. Marcus and Sheehan (9) maintain that cyclizine given prophylactically is more effective than later administration once vomiting has occurred; however, in this series the effect of cyclizine is significant when used postoperatively for the treatment of vomiting. There were not any untoward side-effects observed in the patients treated with cyclizine.

\section{SuMMary}

A study of 1,403 patients has been conducted in relation to the efficiency of certain anti-emetic drugs used before and during operation. The drugs included in the survey were cyclizine and the meperidine-perphenazine, meperidine-promethazine-chlorpromazine sequences. A control group was established in which the patients did not receive any anti-emetic drugs before or during anaesthesia. The distribution of types of major operations and of anaesthetics given in the treated and control groups were compared.

The groups, established apart from the controls, were: $(a)$ meperidine-promethazine-chlorpromazine during operation; $(b)$ meperidine-perphenazine also during operation; $(c)$ cyclizine suppositories $100 \mathrm{mg}$. in the recovery room; (d) cyclizine $50 \mathrm{mg}$. intramuscularly with the preoperative sedation; $(e)$ cyclizine 
$50 \mathrm{mg}$. preoperatively supported by one of the aforementioned meperidine sequences during anaesthesia. The results indicate that cyclizine does not improve the postoperative vomiting to any significant degree, whereas the meperidine tranquillizer sequences show a significant decrease in the incidence of vomiting. A study of the postoperative treatment of 401 patients who vomited within 36 hours of operation indicated that intramuscular administrations of cyclizine produced significant improvement.

\section{ACKNOWLEDGMENTS}

The author wishes to thank the surgeons for their kind co-operation during this study, and also the other members of the Anaesthetic Department for their conscientious assistance throughout. The excellent and detailed records were kept by Miss Robins, Research Assistant to the Anaesthetic Department. Mrs. Harms administered the cyclizine in the Recovery Room. I wish to thank the Board of Governors of the Hospital for their interest, and for the Fellowship Grants to Miss Robins and myself. I am very indebted to Dr. Werner Kalow of the Department of Pharmacology, University of Toronto, for his help and advice on the statistical analyses. I express my gratitude to Burroughs Wellcome and Company for their very practical assistance.

\section{RÉSUMÉ}

Nous avons fait une étude chez 1,403 malades sur l'efficacité de certains médicaments employés comme anti-émétiques avant et durant les opérations. Les médicaments étudiés étaient la cyclizine et la mépéridine-perphenazine, mépéridine-promethazine-chlorpromazine dans l'ordre. Nous avions un groupe de témoins où les malades n'ont reçu aucun médicament anti-émétique ni avant, ni durant l'anesthésie. Nous avons comparé, chez les. deux groupes, le partage des types d'opérations majeures et des anesthésiques donnés.

Le partage des groupes, en-dehors des témoins, étaient comme suit: ( $a$ ) mépéridine-promethazine-chlorpromazine durant l'opération; (b) mépéridine-perphenazine également durant l'opération; $(c)$ cyclizine $100 \mathrm{mg}$. en suppositoires à la salle de réveil; $(d)$ cyclizine 50 mg. I.M. avec la sédation préopératoire; (e) cyclizine $50 \mathrm{mg}$. avant l'operation suivie, au cours de l'anesthésie, d'une des associations à la mépéridine mentionnées antérieurement. Les résultats nous démontrent que la cyclizine n'améliore pas de façon appréciable les vomissements post-opératoires, tandis que l'association mépéridine-tranquillisant a donné une diminution notable de la fréquence des vomissements. Une étude de 401 malades qui ont vomi durant les 36 heures suivant l'opération nous a prouvé que la cyclizine, en injections intramusculaires, a apporté une amélioration notable.

\section{REFERENCES}

1. Marcus, Phulit S., \& Sheehan, John C. Anesthesiology 16 (3): 423-427 (May, 1955).

2. Best, C. H., \& TAyzor, W. B. Physiological Basis for Medical Practice. Baltimore: Williams \& Wilkins Co. (1950). 
3. Dent, Sara J., Ramachandra, V., \& Strephen, (. R. Anesthesiology 16 (4): 564-572 (July, 1955).

4. Robbie, D. S. Anaesthesia 14 (4) : 349-354 (Oct., 1959).

5. Hiebel, G., Bonvallet, M., \& Dell, P. Sein. Hòp. Paris 30: 2346 ( 1954 ).

6. BACK, L. H. N. Am. J. Physiol. 171 (2): 417-435 (1952).

7. Borison, H. L., \& Wang, S. C. Pharmacol. Rev. 5: 193 (1953).

8. Chinn, H. I.; Handford, S. W.; Cone, I. E.; \& Sairth, P. K. Am. J. Med. 12: 433 (April, 1952).

9. Marcus, Phillip S., \& Sheehan, John C. Anesthesiology 16 (3): 423-427 (May, 1955). 